\title{
Individual entrepreneurial orientation on MSME's performance: the mediating effect of employee motivation and the moderating effect of government intervention
}

\author{
Hitesh Kyal, Anirban Mandal, Fedric Kujur and Sriparna Guha
} Brainware University, Kolkata, India

\begin{abstract}
Purpose - This research would like to address the issues associated with individual entrepreneurial orientation, which involves entrepreneurial leadership and entrepreneurial ability as the key determinants of MSME growth. It will also explore both mediating and moderating roles of employee motivation and government intervention, respectively during the pandemic situation.

Design/methodology/approach - A purposive sampling technique was applied during pilot study and during the final data collection phases. Exploratory Factor Analysis (EFA) was conducted using varimax rotation to reduce a large number of variables into a smaller set of interpretable underlying factors. Further CFA and SEM are respectively applied to examine the psychometric properties of the scales and test the hypotheses of the research model.

Findings - The study's findings revealed a favourable association between entrepreneurial orientation, business financing, management, market practices, and MSME growth performance. The results support the notion that government policy plays a significant role as a full moderator.

Practical implications - Although the MSME sector receives government support, its implementation requires a skilled leader who can run the business profitability. The findings support this objective.

Originality/value - This paper seeks to give important insights into one of the understudied but quickly expanding MSME entrepreneurship, and how this environment influences individual entrepreneurial orientation and the formation of entrepreneurial leadership. This opens up a previously unexplored area for fresh insights and future study on enhancing entrepreneurship development research and practice for the MSME sector.
\end{abstract}

Keywords Entrepreneurial leadership, Entrepreneurial orientation, Entrepreneurial ability,

Government intervention, MSME

Paper type Research paper

\section{Introduction}

In India, Micro, Small and Medium-sized Enterprises (MSMEs) play an essential role in expanding their market through new business developments. MSMEs extend their domain through economic sectors to produce various goods and services to respond to domestic and global demands. The available data shows that the MSME sector contributed nearly $30 \%$ of India's Gross Domestic Product (GDP) from 2018-19 (Annual Report, 2020-21, Department

(C) Hitesh Kyal, Anirban Mandal, Fedric Kujur and Sriparna Guha. Published in IIM Ranchi Journal of Management Studies. Published by Emerald Publishing Limited. This article is published under the Creative Commons Attribution (CC BY 4.0) licence. Anyone may reproduce, distribute, translate and create derivative works of this article (for both commercial and non-commercial purposes), subject to full attribution to the original publication and authors. The full terms of this licence may be seen at http:// creativecommons.org/licences/by/4.0/legalcode 
IRJMS

1,1

of MSME, Government of India). It is also the backbone of India's economy in terms of employment generation, reduction of regional economic imbalances and achieving sustainable growth in rural and backward regions of the country. The sector generated around 11.01 crores jobs during the year 2015-16, and most of these jobs were created in micro-enterprises only (Annual Report, 2020-21, Department of MSME, Government of India).

However, the Indian MSMEs also have some restrictions, despite their fast growth and good outlook. The sector often lacks managerial capabilities and technical skills to run a business more efficiently. Even there is government intervention, not all the MSME units can perform as per the expectation. Recent nationwide lockdown due to COVID 19 further worsens the situation (Sahoo and Ashwani, 2020). Most of them do not have adequate direction and expertise to handle the sudden changes in a business situation (Subramaniam and Shankar, 2020). This has severe implications for running and managing organisations (Subramaniam and Shankar, 2020), especially small ones. So, the MSME sectors look for people who display specific entrepreneurial orientation with leadership behaviour. The existing literature on entrepreneurship termed this entrepreneurial orientation a combination of entrepreneurial leadership and entrepreneurial ability (Leitch et al., 2013).

Subsequent separate research in the fields of entrepreneurship and leadership revealed that the performance of small firms depends on the entrepreneurial behaviour of the different stakeholders, including the employees. This is termed as Entrepreneurial Orientation (EO) (Covin et al., 2006). EO is centered on convincing people to comprehend and agree on what needs to be done and the facilitation of individual and community efforts to attain goals via leadership and skill to perform (Leitch and Volery, 2017). It was found that EO has an impact on learning, retention and satisfaction with the business (Sapienza et al., 2005). The principles of $\mathrm{EO}$ were defined at the organisational level as organisational activities such as innovation, risk-taking inclinations, competitive aggressiveness and autonomy. Recently, EO principles have been commonly used at the business level with little consideration for the individual entrepreneurial orientation (IEO) (Goktan and Gupta, 2015). According to some researchers, EO has three dimensions: innovativeness, proactiveness, and risk-taking (Wiklund and Shepherd, 2005). Others have seen the same notion as having five dimensions: autonomy, innovation, risk-taking, proactiveness, and competitive aggressiveness. Some researchers use a different set of five dimensions: achievement, personal control, innovation, self-esteem, and opportunism (Shanthakumar, 1992), and one researcher even added two more dimensions to the previous model: risk-taking and independence (Josien, 2012).

As the present business climate evolves to a more community-based, local market, this increases the number of individual start-ups and small-enterprise operations. With this development comes the necessity for an individual to analyse their capacity to enter the sector (Vogelsang, 2015). Since the early 1990s, research based on entrepreneurial leadership has developed substantially. A new type of entrepreneurial leadership has emerged that considers the specificities of leadership in micro and small businesses rather than huge organisations (Harrison et al., 2018; Dabic et al., 2021). It is the process of "influencing and guiding individuals' performance to achieve those organisational goals that entail detecting and exploiting entrepreneurial possibilities". On the other hand, Entrepreneurial Ability (EA) refers to an individual's confidence in his or her capacity to accomplish entrepreneurshiprelated activities, and it is a crucial strategy for overcoming perceptions of risk connected with new venture development (Amini Sedeh et al., 2021; Ranjan and Panicker, 2020).

Thus, the Individual Entrepreneurial Orientation (IEO) is an extension of EO (Musara and Nieuwenhuizen, 2020), and it is characterised as the tendency of persons to behave proactively, innovatively in a risky business environment (Jong et al., 2015). IEO is also influenced by the entrepreneurial ability of the person leading the organisation. The promotion of entrepreneurship needs people to take specific measures to initiate and execute 
new business development practices. A variety of cognitions were discovered that affect this behaviour, including risk perception (Renko et al., 2012), the perception of getting an opportunity (Sarasvathy et al., 2003) and the perception of having the entrepreneurial ability (Arenius and Minniti, 2005). In this paper, the authors would like to address the impact of this entrepreneurial ability along with entrepreneurial leadership on IEO.

\subsection{Problem statement}

Entrepreneurial leadership has been used in general as a tool to define the management, production and growth problems of small and medium enterprises (SMEs). Leitch and Volery (2017) have placed entrepreneurial leadership as a connection between leadership and entrepreneurship. Different scholars who attempt the definition of entrepreneurial leadership have recognised that it includes qualities, such as attitude, style, marketing management, internal activities and external business circumstances, given its characteristics and roots (Simba and Thai, 2019). The available literature shows that along with a favourable or challenging business condition, it is essential to have a person who has the qualifications to run the enterprise. This requires specific skills that are known as individual entrepreneurial orientation, which is a byproduct of entrepreneurial leadership (Simba and Thai, 2019) and entrepreneurial ability (Sengupta et al., 2013).

Moreover, entrepreneurial leaders are expected to empower people to go beyond selfinterest and work on group objectives to encourage staff engagement, initiative, and success (Judge and Piccolo, 2004). Various literature focused on the impact of human resource performance on a firm's sustainable growth. A commitment to sustainability would enable organisations, staff, consumers, and immediate social communities to establish partnerships with their main stakeholders to implement their sustainability agenda (Daily and Huang, 2001).

In an emerging country like India, the role of government support in the MSME sector cannot be ignored. There is a great deal of concern and discussions worldwide on the effect of size and the extent of government policy on economic development. Many aspects of government policy have an impact on the degree of entrepreneurship. Some of the possibilities will be determined by the population's attitude towards entrepreneurship, labour force structure, government size and function, and entrepreneurial activity and MSMEs already in existence (Khaksar, 2011). MSMEs may directly alleviate poverty by boosting income levels and providing jobs. Therefore, it is usual for governments to establish policies to support their growth (Khaksar, 2011). An evaluation of MSMEs and their performance in relation to government policies and support is provided in this study. Thus, the authors would like to introduce government intervention as a moderating variable in the model to see the impact on the MSME performance.

The authors have deliberated about the review of literature, methodology and have done analysis in the following sections. At the end of the paper, discussions and conclusions have also been added to address the research objective.

\section{Review of literature}

\subsection{Entrepreneurial leadership and individual entrepreneurial orientation}

Entrepreneurial leadership is seen as an important factor in the growth of a new enterprise and is viewed as a power that supports the drive towards development (Leitch et al., 2013). Empirical studies have recognised the impact of entrepreneurial leadership on successful outcomes, linking its influence to SME growth (Koryak et al., 2015), highlighting commitment and focusing on adaptation in high-speed development or underlining the achievement of organisational goals (Renko et al., 2015). These approaches combine leadership with 
IRJMS

1,1

entrepreneurship as a special case of leadership in a business context (Cogliser and Bigham, 2004). Previous business leadership analyses (Leitch et al., 2013) showed that it is a socially built phenomenon that can be assessed and addressed in various fascinating ways. A relationship has to develop between the owners and the employees in an organisation to run the business profitably. While EO offers guidance for companies to explore new business prospects, some scholars said that it was vital to investigate the effects of successful leadership in EO adoption (Hmieleski et al., 2012). Though most of the literature focused on the relationship between entrepreneurial leadership and $\mathrm{EO}$, not much attention was given to IEO from the purview of small business sectors. The person having IEO is expected to behave like the owners and drive the growth of the organisation. Hence, the first hypothesis proposed as:

H1. There is a positive relationship between entrepreneurial leadership and IEO.

\subsection{Entrepreneurial ability and individual entrepreneurial orientation}

IEO has a Behavioral aspect that shows the ability of the individual to remain innovative, proactive in the organisation, and willing to take the risk associated with the business (Jong et al., 2015). Though the firm's leadership has an influence on IEO, it is not the only factor that influences it. Leaders should have the ability to run a business with the help of the given resources. However, IEO is not the outcome of entrepreneurial leadership only. The entrepreneurial ability of the person also greatly influences the IEO. Entrepreneurial ability is a combination of two important factors, viz., innate talent and continuous improvement of this talent (Sengupta et al., 2013). It is discussed in various literature that desire for profit (Bosma et al., 2012), social ties and networks (Hoang and Antoncic, 2003), prior experience, parental work background (Vaillant and Lafuente, 2007), awareness about one's entrepreneurial abilities (Bayon et al., 2015), market orientation are important factors that lead to enhance the entrepreneurial ability of an individual. Thus, a collective impact of entrepreneurial leadership and entrepreneurial ability can boost the individual entrepreneurial orientation and, subsequently the performance of the small business segment. Thus, the proposed hypothesis is:

H2. There is a positive relationship between entrepreneurial ability and IEO.

\subsection{Individual entrepreneurial orientation and improved MSME performance}

Due to unemployment, many people are looking to establish their own businesses. These individuals may have a desire to become entrepreneurs, but they may lack the necessary competencies to compete in this dynamic business environment (Khan et al., 2020). Due to the competitive nature, it is essential to comprehend and build entrepreneurial orientation (EO) by updating competencies. Researchers such as Quince and Whittaker (2003) and Jogaratnam (2017) have all found a favourable link between EO and the performance of MSME. Dependent factors that are more directly sensitive to $\mathrm{EO}$ and contingent variables should be studied to understand the connection between EO and SME's performance (Chiva et al., 2007). Organisational mechanisms affect growth as productive capital reserves are generated or leveraged. It's been shown in an empirical study that the benefits of entrepreneurial orientation can take many years to manifest and that company's success is highly dependent on a wide range of internal as well as external organisational factors and variables (Thoumrungroje and Tansuhaj, 2005). Additional dependent variables are more directly related to the entrepreneurial orientation that may be used to model the link between entrepreneurship and business performance (Muhammed and Abdulkadir, 2021; Kittikunchotiwut, 2020). Some of the important components of organisational resources are intellectual capital, human capital and social capital (Hayton, 2005). These resources can 
create competitiveness in any organisation. There were the firm's own 'organisational skills' and "entrepreneurial competencies," which represent the owner-driven behaviour (Man et al., 2002). Finally, long-term success includes reliability, sustainability, progress, and profitability (Hurley, 2018; Muhammed and Abdulkadir, 2021). To achieve this goal, it is important to have an individual who has the required skills and expertise. Within a small indigenous company, skilled expertise makes a significant contribution to organisational productivity (Baldacchino, 2011). Thus, it is expected that the human capital coupled with IEO is helping the growth of small firms in any economy.

Hence, we propose that:

H3. There is a positive relationship between IEO and improved MSME performance.

\subsection{Individual entrepreneurial orientation and employee motivation}

MSMEs face significant challenges in terms of employee satisfaction, organisational commitment, and organisational efficiency, especially in emerging economies (Farooq et al., 2015). In various literature, it is shown that employee satisfaction leads to employee performance (Lavelle et al., 2010) and subsequently improves the productivity of the firm. However, the different dimensions of IEO have a direct impact on employee performance. The five dimensions of the IEO, such as innovativeness, risk-taking ability, proactiveness (Soomro and Shah, 2019), aggressiveness and autonomy are expected to influence the behaviour of the employees as well. If the leader is creative, then it will help to improve the employee motivation as they will also involve in the innovative business environment, and this will help to improve the firm's performance. Hence, an employee, getting a competitive environment in a workplace, tends to behave in a similar manner. Lastly, autonomy gives more freedom and motivates the workforce to work for the betterment of the organisation (Soomro and Shah, 2019). Hence, the authors suggest that:

\section{H4. There is a positive relationship between IEO and employee motivation.}

2.4.1 Mediating role of employee motivation on MSME performance. Existing research looks at entrepreneurial orientation from the perspective of a company. Innovativeness is one of the elements of entrepreneurial orientation that is rooted in personal and group activities within organisations (Messersmith and Guthrie, 2010). A strategic framework involving human resources, social capital, and employee attitudes is required to link HRM activities and organisational success. Employees' competencies and knowledge are shaped in a corporate atmosphere that promotes learning and fosters entrepreneurial orientation (Bal et al., 2014), which directly impacts the company's efficiency (Jyoti et al., 2017). In MSME units, on the other hand, the leader wins employee support and confidence by exploiting their familiar ties and primarily designing casual HR activities (Garavan et al., 2016). Hence, the proposed hypothesis is:

H4a. Employee motivation positively mediates the IEO and MSME performance.

\subsection{Government intervention and MSME performance}

Previous studies have described factors such as a lack of institutional climate, lack of policy support and lack of mechanisms and guidance as major obstacles to SMEs (Krauss et al., 2010). For many policymakers, MSMEs have been a critical issue when trying to increase the rate of growth in low-income nations. Despite the elements that contribute to the economic success of MSMEs, there are worries about their long-term viability. Due to the previous paradigm of economic growth during the reform period, which concentrated on large-scale enterprises to increase exports, there has been a lack of enthusiasm and effort in the expansion of small and medium-sized businesses. Therefore, capital and a lack of infrastructure and human resource capacity building become major obstacles for MSMEs 
IRJMS 1,1

\section{6}

Figure 1.

The proposed conceptual model to grow and expand successfully (Kusumawardhani et al., 2015). Government policy has a major effect on SMEs' productivity (Das and Rangarajan, 2020). The efficiency of SMEs varies depending on the government policies they choose (Eniola and Entebang, 2015). In India, the regional distribution of SMEs is far broader, which can be effectively leveraged in the inclusive development process. The government will play an important role by imposing mandatory responsible commercial practice obligations on SMEs (Das and Rangarajan, 2020). It is argued that government policies and supports should not be restricted to financial aid only (Banjo and Doren, 2012); rather, it should go beyond that and may focus on training and skill development of the employees as well as leaders. Regulatory policies, trade policies, labour market policies, regional development policies, social policies, and even gender policies of the government all have an impact on entrepreneurial activity (Ranjan and Panicker, 2020). This would rely on various factors, including the population's attitude towards entrepreneurship, labour force structure, the size and function of government, the prevalence of entrepreneurial activity, and the number of MSMEs in the country (Socrates and Gopalakrishna, 2020). To boost the number of new entrepreneurs and start-ups, the government must provide a supportive environment that encourages the appropriate individuals to become entrepreneurs and improves the quality of existing companies (Socrates and Gopalakrishna, 2020; Ranjan and Panicker, 2020).

On the other hand, government intervention is expected to further moderate the individual entrepreneurial orientation and subsequently improve the MSME performance. Because of this intervention, it is expected that the owners of the MSME units can grow during an adverse situation. So, the authors proposed that if there is an improvement in IEO because of government intervention, it will further improve the MSME performance.

Hence, the authors proposed the following hypotheses by taking government intervention as an important factor:

H5. There is a positive relationship between government intervention and MSME performance.

H5a. Government intervention positively moderates the IEO and subsequently the performance of MSME.

A conceptual model is developed based on a literature review to see the relationship among the dependent (MSME performance) and independent variables. The conceptual model has been presented in Figure 1.

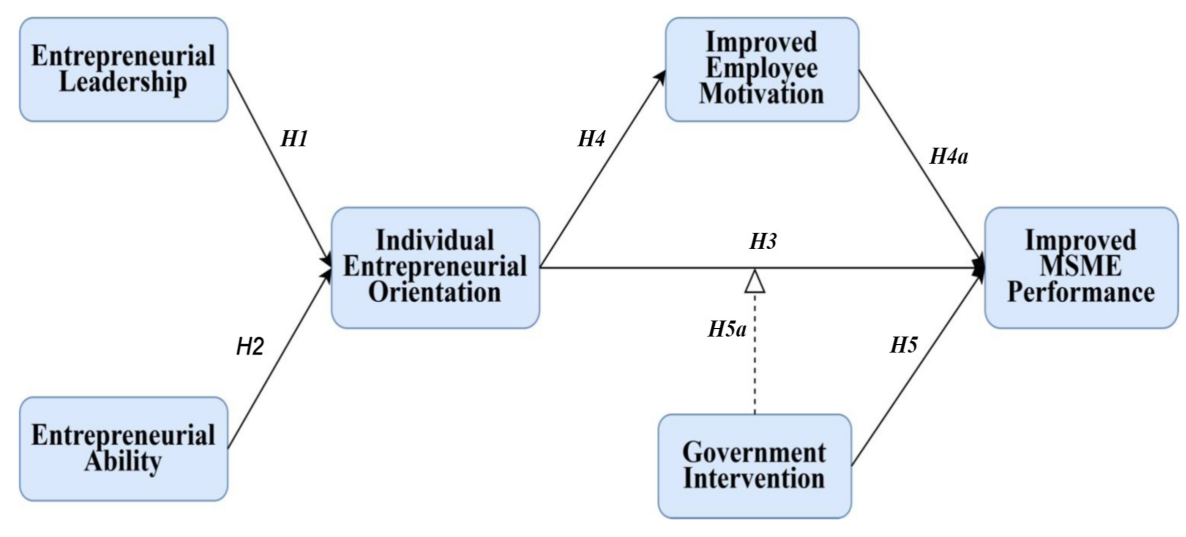

Source(s): Conceptualised by Authors 


\section{Methodology}

\subsection{Selection of study area and sample respondents}

A comprehensive list of data related to the MSME sector is available in an MSME Annual report published by the Government of India. However, the report is full of information but not very specific to any particular states. In India, the MSME sector is divided into three categories: micro, small and medium enterprises based on the MSMED Act, 2006 and subsequent revision implemented on 1st June, 2020. According to the Government of West Bengal, MSME Department, the MSME sectors are divided into 17 clusters, spread across 23 districts. Among these 17 clusters, the metal fabrication and furniture sector have the highest number of clusters (184 clusters). Thus, the authors selected this cluster for this study. Since the concentration of clusters is higher in Paschim and Purba Medinipur districts of West Bengal (total 3400 MSME Units), according to the MSME website of Government of West Bengal, it has been decided to select these two districts as study districts.

In this study, the sample respondents are the MSME players leading the organisation. But, in some cases (mostly for micro-enterprises), due to the small nature of their operation, it was observed that there is hardly any difference between the immediate manager and owner. So, for those cases, the information was collected from them as well. A purposive sampling technique was applied during the pilot study as well as during the final data collection phases. The final stage of the survey was conducted from January 2021 to March 2021, after the complete lockdown was withdrawn and the units were back to normal. This was done to see the impact of government intervention on MSME units in the study areas.

\subsection{Scale development}

The main important variables in this study are entrepreneurial leadership, entrepreneurial ability, IEO and MSME performance. Two more variables are added; namely, employee motivation and government intervention, to see the mediating and moderating effects on MSME development, respectively.

The constructs for entrepreneurial leadership were developed by Musara and Nieuwenhuizen (2020) which includes eight items. 8 point entrepreneurial leadership has three constructs, namely, care for others (4 items), having a vision (3 items), opportunity oriented (3 items). Entrepreneurial ability is measured with the help of 6 constructs, namely; desire for profit (3 items) (Bosma et al., 2012), social ties and networks (3 items) (Hoang and Antoncic, 2003), prior experience (2 items) parental work background (2 items) (Vaillant and Lafuente, 2007), awareness about one's own entrepreneurial abilities (2 items) (Bayon et al., 2015), and market orientation (4 items). Since it is argued that IEO is an extension of EO, the authors suitably modified the scale developed by Musara and Nieuwenhuizen (2020). Many researchers (Musara and Nieuwenhuizen, 2020; Ebrahimi and Mirbargkar, 2017) incorporated 3 dimensions of IEO (proactivity, innovativeness and risk taking). After adding two more dimensions, the same has been extended, namely, aggressiveness and autonomy. The modified scale incorporated in this study has five constructs, namely, proactivity (3 items), innovativeness ( 3 items), risk-taking (3 items), aggressiveness ( 3 items) and autonomy (3 items). Further, a 9 item SME scale is incorporated in the present study as developed by (Ebrahimi and Mirbargkar, 2017). The constructs for this scale are increased employment (3 items), financial performance (3 items) and expansion of an existing business or venture into a new business (3 items). In this study, the mediating variable is employee motivation. The mediating variable items (3 items) are developed from existing works by different scholars (Garavan, 2016; Maheshwari et al., 2020; Mehta and Kaur, 2021). Lastly, government intervention is measured on a categorical scale using two variables: awareness about policy initiatives and participation in government-sponsored schemes (Socrates and Gopalakrishna, 2020). 


\section{IRJMS 1,1}

\section{Analysis}

The initial result shows that out of the total number of participants, around $23 \%$ are from medium enterprises, $31 \%$ are from small enterprises, and $46 \%$ are from micro-enterprises. So, the concentration of micro-enterprises is more in metal fabrication and furniture clusters. On average, $40 \%$ of the workforce are regular in nature, while the rest of the workforce is casual. Most of these causal workers are doing routine jobs. They do possess some skills related to metal fabrication. However, the percentage of skilled workforce is less in micro-enterprises. Around $80 \%$ of the workforce in micro-enterprises do not have adequate training, and most of these units are family-owned. So, the skills that they possess are gained from senior family members. Around $75 \%$ of medium and $62 \%$ of small units use technology-based production facilities, and most of the training is arranged for this group of employees. Usage of technology is substantially low in micro enterprises (around 14\%). There is a variation in access to finance, market access, and government benefits among these three units. While the key to these resources is more for medium and small enterprises, the same may not be the case for micro-enterprises.

In order to measure items as mentioned above, the study used a five-point ordinal (Likert) scale from 1 = "strongly disagree" to 5 = "strongly agree".

Further CFA and SEM are respectively applied to examine the psychometric properties of the scales and test the hypotheses of the research model using statistical software AMOS version 21. Several statistical tests and criteria like Cronbach's Alpha values, composite reliability, and convergent and discriminant validity are included. In addition, thorough testing of assumptions for multivariate techniques and preliminary data analyses was carried out, including "multiple imputations" of missing data, normality and outlier analysis.

\subsection{Confirmatory Factor Analysis (CFA)}

CFA is commonly used to check the accuracy of constructing indicators with the researcher's knowledge of the construct's existence (or factor). CFA First Order analysis is performed to validate each indicator variable to its representative factor concerning previous/past literature. In CFA, exogenous and endogenous variables are combined or pooled to make simpler and better individual CFA, mainly when performing the measurement model (Chong et al., 2014).

The present study has applied measurement model using both First Order CFA and Second Order CFA for the construct validity and reliability and for checking the strength of item indicators adopted and modified by the researchers. The results of the CFA First Order indicated a good measurement model fit of the proposed factor structure $(\mathrm{CMIN} / \mathrm{DF}=1.634, \mathrm{GFI}=0.907$, $\mathrm{NFI}=0.917, \mathrm{IFI}=0.966, \mathrm{TLI}=0.961, \mathrm{CFI}=0.966, \mathrm{PCFI}=0.841, \mathrm{RMSEA}=0.033$, $\mathrm{RMR}=0.032$ ). Further, the results of CFA Second Order also indicated a good measurement model fit of the proposed factor structure $(\mathrm{CMIN} / \mathrm{DF}=1.677$, GFI $=0.901$, NFI $=0.912$, $\mathrm{IFI}=0.962$, $\mathrm{TLI}=0.958, \mathrm{CFI}=0.962, \mathrm{PCFI}=0.861, \mathrm{RMSEA}=0.034, \mathrm{RMR}=0.038$ ).

Table 1 presents the validity and reliability of both first order and second order constructs.

A structural model was built to examine the causal relationship among the constructs in the research model. The structural model was evaluated by examining the standardised path coefficients, $t$-statistics, and their statistical significance for testing hypotheses. The model-fit indices for structural model provided evidence of comparatively good model fit (Chisquare $=1,147.007, \mathrm{CMIN} / \mathrm{DF}=2.896, \mathrm{GFI}=0.856, \mathrm{NFI}=0.873, \mathrm{IFI}=0.913, \mathrm{TLI}=0.904$, $\mathrm{CFI}=0.913, \mathrm{RMSEA}=0.065, \mathrm{RMR}=0.115)$. The hypothesised results have been shown in Table 2.

In addition to it, the present study also checked the indirect effects to test for the mediating effect of Individual Employee Motivation (IEM) between IEO and IP. In order to test mediation analysis, the present study followed the Hayes (2009) and Zhao et al. (2010) threestep measurement model for mediation. The first step includes whether the independent variable is a significant predictor of the dependent variable. The second step includes 

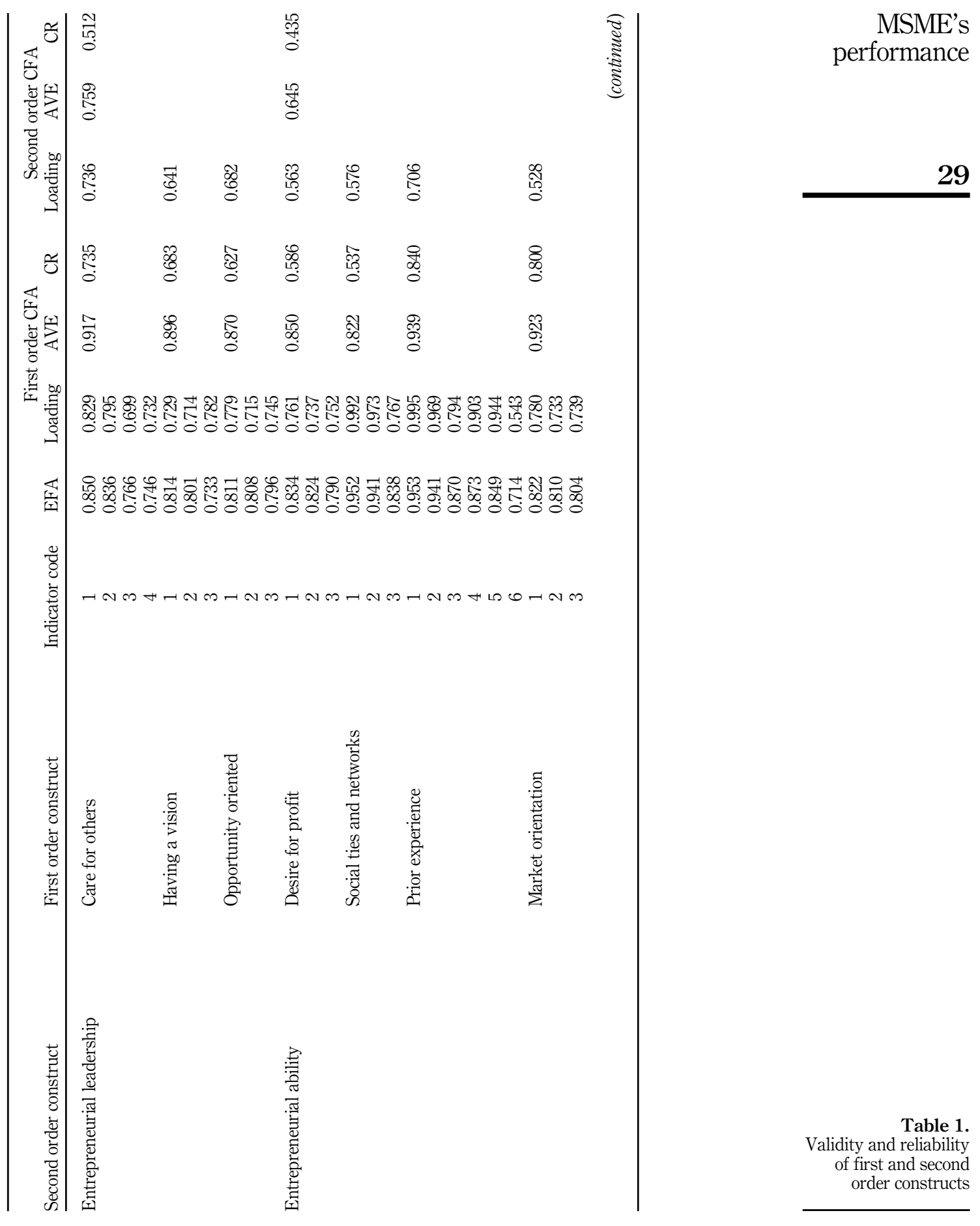

Table 1.

Validity and reliability of first and second order constructs 


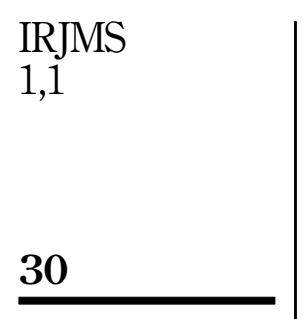

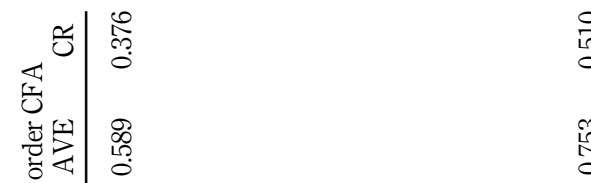

ֻุำ

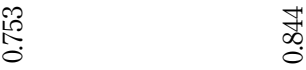

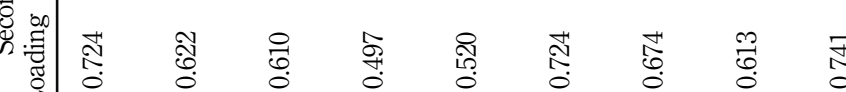

$\rightarrow$

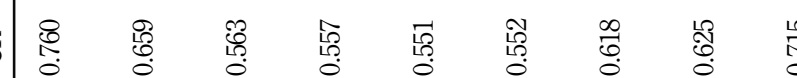

岳山䁶

范

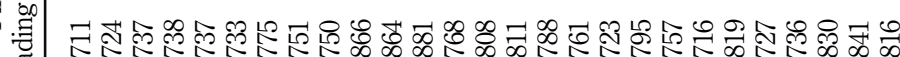

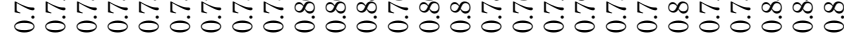

雨

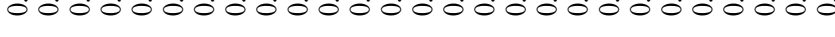

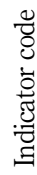

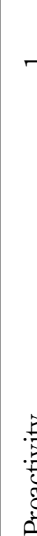

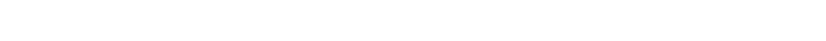

宇

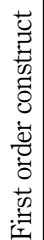

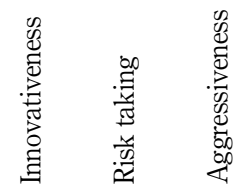

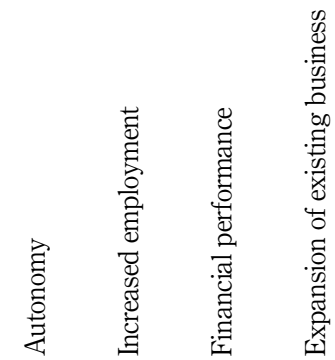

.气.

Table 1.

击

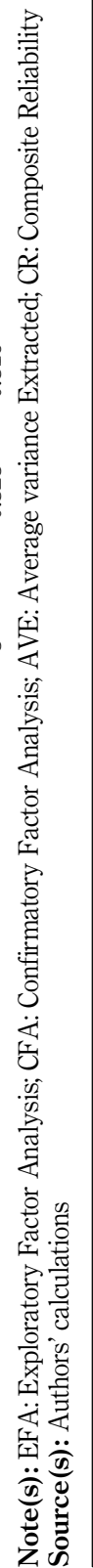




\begin{tabular}{|c|c|c|c|c|c|c|c|}
\hline Hypotheses & Path & & & Standardized estimate & SE & $\mathrm{CR}$ & $p$ \\
\hline $\mathrm{H} 1$ & $\mathrm{EL}$ & $\rightarrow$ & IEO & 0.334 & 0.024 & 5.759 & $*:$ \\
\hline $\mathrm{H} 2$ & $\mathrm{EA}$ & $\rightarrow$ & IEO & 0.403 & 0.036 & 6.232 & $* *$ \\
\hline H3 & IEO & $\rightarrow$ & $\mathrm{IP}$ & 0.167 & 0.053 & 2.945 & 0.003 \\
\hline $\mathrm{H} 4$ & IEO & $\rightarrow$ & IEM & 0.288 & 0.053 & 4.941 & $* *$ \\
\hline H5 & IEM & $\rightarrow$ & $\mathrm{IP}$ & 0.211 & 0.060 & 3.584 & $* * *$ \\
\hline H6 & Govt & $\rightarrow$ & IP & 0.279 & 0.055 & 5.469 & $* *$ \\
\hline
\end{tabular}

Entrepreneurial Ability; IEO: Individual Entrepreneurial Orientation; IEM: Individual Employee Motivation; IP: Individual Performance

Source(s): Authors' calculations

MSME's
performance

Table 2.

Result of SEM model

whether independent variable is a significant predictor of the mediator. The third step includes whether the mediator is a significant predictor of the dependent variable. From Table 3, it is evident that IEO mediates the relationship between IEM and IP as the coefficient value of the total effect is greater than the direct effect.

\subsection{Multi-group moderation analysis-govt. Intervention}

The present study also carried out multi-group moderation analysis to check moderating/ interacting effect of government intervention between Individual Entrepreneurial Orientation (IEO) and MSME Performance. The data of government intervention was split into two groups "Participants" of government-sponsored schemes and "non-participants" for comparison purposes using SPSS "split file" command on the demographic variable. AMOS generates a pairwise parameter comparison matrix that tests all of the pairwise differences between the model parameters generating $z$-scores. To measure the moderating effect $z$-score above 1.96 is generally considered. Using these values as critical ratios, the regression weights for each pair of relationships in the model can be compared between the groups (Radomir and Nistor, 2013).

Multi-group moderator analysis was performed to determine whether the Government intervention between Individual Entrepreneurial Orientation and MSME Performance is different for Participants and Non-participants of govt. Sponsored schemes. Based on the $Z$ scores, results indicate (Table 4 ) that the relationships which are moderated by government intervention at 95\% confidence level are relationships between Individual Entrepreneurial

\begin{tabular}{lcccccccc}
\hline IV & MV & DV & IV $\rightarrow$ DV & IV $\rightarrow$ MV & MV $\rightarrow$ DV & Indirect effect & Total effect & Hypothesis \\
\hline IEO & IEM & IP & 0.167 & 0.288 & 0.211 & 0.061 & 0.227 & Accepted
\end{tabular}

Note(s): IEO: Individual Entrepreneurial Orientation; IEM: Individual Employee Motivation

Source(s): Authors' calculations

Table 3.

Mediation analysis: Standardized regression weight

\begin{tabular}{|c|c|c|c|c|c|c|c|}
\hline \multirow[b]{2}{*}{ Constructs } & \multicolumn{2}{|c|}{$\begin{array}{l}\text { Govt. } \\
\text { Participants of govt. } \\
\text { Sponsored scheme }\end{array}$} & $\begin{array}{l}\text { rention } \\
\text { Non-pe }\end{array}$ & ants & \multirow[b]{2}{*}{$Z$-Value } & \multirow[b]{2}{*}{ Relationship } & \multirow{4}{*}{$\begin{array}{r}\text { Table } 4 . \\
\text { Moderation analysis: } \\
\text { government } \\
\text { intervention }\end{array}$} \\
\hline & Estimate & $p$-value & Estimate & $p$-value & & & \\
\hline $\mathrm{EA} \rightarrow \mathrm{IEO}$ & 0.405 & $* * *$ & 0.158 & 0.056 & 4.028 & Supported & \\
\hline \multicolumn{7}{|c|}{$\begin{array}{l}\text { Note(s): EA: Entrepreneurial Ability; IEO: Individual Entrepreneurial Orientation } \\
\text { Source(s): Authors' calculations }\end{array}$} & \\
\hline
\end{tabular}


IRJMS 1,1

\section{2}

Orientation and MSME Performance. This relationship was found to be moderated by government intervention with $Z$-value 4.028 . The strength of moderation for the path IEO to MSME Performance $\left(0.405^{* * *}\right)$ was increased by the participants of the governmentsponsored schemes group. This implies that the moderating effect of governmentsponsored schemes participants have a higher impact on this relationship than the nonparticipants.

\section{Discussion}

Empirical findings and theoretical consequences are explored in this section. The results of this study are presented in the order in which the underlying hypotheses were tested. We'll start by talking about the findings. Entrepreneurial leadership is regarded as an important aspect in developing a new business and as a driving force that promotes advancement. Empirical studies have acknowledged the impact of entrepreneurial leadership on successful outcomes, correlating its influence to SME growth, emphasising dedication and focusing on adaptation in high-speed and specific situations, or emphasising the achievement of organisational goals. The findings showed that entrepreneurial leadership positively influenced individual entrepreneurial orientation and innovative behaviour via entrepreneurial self-efficacy. It has been seen in the previous literature also that taking advantage of their workers' potential to innovate is one approach for firms to become more inventive. Employees can contribute to increase performance by generating new ideas and implementing them in new and improved goods, services, and work processes (Leitch et al., 2013; Koryak et al., 2015; Renko et al., 2015).

Furthermore, individual entrepreneurial orientation is associated with the generation or adoption of good ideas and their implementation. There is also evidence that a resource-based perspective on the firm improves business performance. This hypothesis revealed the same that entrepreneurial leadership has an affirmative impact on individual entrepreneurial orientation.

It has also been seen that individual entrepreneurial orientation has a behavioral component that demonstrates the individual's ability to remain imaginative, proactive in the company, and willing to take risks associated with the firm. Previously, many extant studies by Sengupta et al. (2013), Bosma et al. (2012), Bayon et al. (2015) confirmed the same. As a result, the finding supported that when a person can identify and capitalise on a business opportunity, that person is judged to have a higher potential to be an entrepreneur. Meanwhile, innovation is associated with the use of new ideas to create new products, services, or processes. Because of the increasingly competitive business world, current entrepreneurs must be inventive.

Furthermore, organisational mechanisms of MSMEs influence growth by generating or leveraging productive capital reserves. Financial resources, intellectual capital, human capital, and social capital are all key components of organisational resources. These resources have the potential to boost competitiveness in any firm. The research demonstrated that the essential dimensions of EO driving MSMEs performance include innovativeness, risk-taking, proactiveness, autonomy, achievement, and learning orientations. These findings are consistent with earlier research (Porter and Kramer, 2002; Hurley, 2018) that show a strong link between the existence of these leadership characteristics and a favorable impact at the personal, team, and organisational levels, with the most significant boost to the performance of MSME.

Employee satisfaction has been proven in many studies to contribute to improved employee performance (Lavelle et al., 2010) and, as a result, firm productivity increases. Despite this, few studies have examined the impact of the entrepreneurial approach and corporate culture on worker engagement, organisational engagement, and employee performance (Panagiotakopoulos, 2013). Many researchers, such as Baard et al. (2014), Soomro and Shah (2019), provided that competitive aggressiveness and a proactive mindset and employee motivation can be linked to success in a number of ways. It is clear from the 
results that managers must develop innovative strategies to keep their personnel as motivated as possible continually. Because of the benefits that it can bring, motivation is critical for every business.

Another important finding is that employee motivation mediates the IEO and the performance of the MSME. According to the analysis, the validity of hypothesis (H4a) means that as motivation improves, so does performance: when an employee is highly driven, he or she will perform well at work. The findings suggest that motivation has a mediating effect on individual entrepreneurial orientation and employee performance, supporting previous studies such as Jyoti et al. (2017), Maheshwari et al. (2020). As a result, organisational commitment is critical and highly significant in the workplace, boosting worker performance. An organisation must have comprehensive levels of employee commitment to have great long-term performance.

Lastly, the study also states that Government intervention positively moderates the IEO and the performance of MSME, where government intervention has a positive impact on both. Previous research identified a lack of institutional climate, a lack of legislative support, and a lack of tools and direction as primary barriers to SMEs in emerging countries engaging in sustainable management activities (Krauss et al., 2010). But recently, many studies confirmed that Government policy has a significant impact on the productivity of SMEs (Das and Rangarajan, 2020; Eniola and Entebang, 2015). Our study also confirms the same and reinforces the importance of government intervention on IEO and employee performance, as done by Socrates and Gopalakrishna (2020). The study revealed a favorable association between entrepreneurial values, business financing, management, market practices, and SME growth performance. The findings further support the notion that government policy plays a significant role as a full moderator in such connections.

Entrepreneurship is becoming more popular throughout the world, and India is no exception. People are presently contacting numerous start-ups to tackle the country's unemployment problem due to limited access to work for the young. In this context, this study offers many insights to businesses to help them understand the significance of IEO, EL and EA. It is a clear indicator for MSMEs "managers and owners to create the IEO to improve their enterprises" performance. Along with this, they must focus on IEM to create greater opportunities for businesses. However, it is also the government's obligation to ensure adequate resources for expanding chances for improved IEO and MSME performance. Finally, the emphasis should be on solving problems or providing the finest services to clients through start-ups to make entrepreneurial firms more successful and long-lasting.

\section{Conclusion and limitation}

There has been much written on the importance of MSME sector entrepreneurship, but less has been written about its role in IEO and the rise of entrepreneurial leadership. This article examines the connection between IEO, employee motivation, and government intervention using a primary database of 243 units and finds the results. Our research provides two significant contributions to the realm of entrepreneurship. Based on the results and following the discussions, it can be said that employee motivation positively mediates the IEO and MSME performance, and secondly, government intervention positively moderates the IEO and subsequent performance of MSME. The findings of this article contribute to our knowledge of how penurious settings, such as MSME entrepreneurial environments, provide a foundation for IEO and, ultimately, entrepreneurial leadership behaviour. Simultaneously, the literature emphasises the importance of IEO and entrepreneurial leadership in supporting the formation and success of entrepreneurial orientations. The study's methodological approach contributes to the assessment of individual entrepreneurial orientation and performance of the employee. The study has certain 
IRJMS

1,1

limitations, particularly in terms of MSMEs' heterogeneity, where the product sector could be used to complete multi-group analysis. We recommend that future research expands its coverage across India in order to gain a better knowledge of the strategic activities of small and micro firms in India.

Nonetheless, we think that the findings of this study have contributed to a better understanding of the entrepreneurial ability and strategic behaviour of MSME in general. Policymakers will be able to utilise this information to design appropriate programmes to enhance the sustainability of this industry. While India was the focus of this paper's research, this work may be expanded to analyse and improve the support measures available to MSMEs in other developing nations in addition to India.

\section{References}

Amini Sedeh, A., Abootorabi, H. and Zhang, J. (2021), "National social capital, perceived entrepreneurial ability and entrepreneurial intentions", International Journal of Entrepreneurial Behavior and Research, Vol. 27 No. 2, pp. 334-355.

Annual Report (2020-21), Department of MSME, Government of India, available at: chromeextension://efaidnbmnnnibpcajpcglclefindmkaj/viewer.html?pdfurl=https $\% 3 \mathrm{~A} \% 2 \mathrm{~F} \% 2 \mathrm{Fmsme}$. gov.in $\% 2$ Fsites $\% 2$ Fdefault $\% 2$ Ffiles \%2FMSME-ANNUAL-REPORT-ENGLISH $\% 25202020-21$. pdf\&clen $=8006666 \&$ chunk $=$ true $($ accessed 26 May 2021).

Arenius, P. and Minniti, M. (2005), "Perceptual variables and nascent entrepreneurship", Small Business Economics, Vol. 24 No. 3, pp. 233-247.

Baard, S.K., Rench, T.A. and Kozlowski, S.W. (2014), "Performance adaptation: a theoretical integration and review", Journal of Management, Vol. 40 No. 1, pp. 48-99.

Bal, E. and Kunday, A.Ö. (2014), "Investigating the role of entrepreneurial traits and human capital on the internationalisation degree of small and medium enterprises in Turkey", International Journal of Business and Social Science, Vol. 5 No. 8, pp. 192-201.

Baldacchino, G. (2011), "Small island entrepreneurship", World Encyclopedia of Entrepreneurship, Edward Elgar Publishing.

Banjo, R. and Doren, C. (2012), "Environmental sustainability orientation and financial resources of small manufacturing firms in the Philippines”, Social Responsibility Journal, Vol. 8 No. 2, pp. 208-226.

Bayon, M.C., Vaillant, Y. and Lafuente, E. (2015), "Antecedents of perceived entrepreneurial ability in Catalonia: the individual and the entrepreneurial context", Journal of Global Entrepreneurship Research, Vol. 5 No. 1, pp. 1-19.

Bosma, N., Hessels, J., Schutjens, V., Van Praag, M. and Verheul, I. (2012), "Entrepreneurship and role models", Journal of Economic Psychology, Vol. 33 No. 2, pp. 410-424.

Chiva, R., Alegre, J. and Lapiedra, R. (2007), "Measuring organisational learning capability among the workforce", International Journal of Manpower, Vol. 28 Nos 3-4, pp. 224-242.

Chong, E.E., Nazim, A. and Ahmad, S.B. (2014), "A comparison between individual confirmatory factor analysis and pooled confirmatory factor analysis: an analysis of library service quality, a case study at a public university in Terengganu", International Journal of Engineering Science and Innovative Technology, Vol. 3 No. 1, pp. 110-116.

Cogliser, C.C. and Brigham, K.H. (2004), "The intersection of leadership and entrepreneurship: mutual lessons to be learned”, The Leadership Quarterly, Vol. 15 No. 6, pp. 771-799.

Covin, J.G., Green, K.M. and Slevin, D.P. (2006), "Strategic process effects on the entrepreneurial orientation-sales growth rate relationship", Entrepreneurship Theory and Practice, Vol. 30 No. 1 , pp. $57-81$.

Dabić, M., Stojčić, N., Simić, M., Potocan, V., Slavković, M. and Nedelko, Z. (2021), "Intellectual agility and innovation in micro and small businesses: the mediating role of entrepreneurial leadership", Journal of Business Research, Vol. 123, pp. 683-695. 
Daily, B.F. and Huang, S. (2001), "Achieving sustainability through attention to human resource factors in environmental management", International Journal of Operations and Production Management, Vol. 21 No. 12, pp. 1539-1552.

Das, M. and Rangarajan, K. (2020), "Impact of policy initiatives and collaborative synergy on sustainability and business growth of Indian SMEs", Indian Growth and Development Review, Vol. 13 No. 3, pp. 607-627.

Ebrahimi, P. and Mirbargkar, S.M. (2017), "Green entrepreneurship and green innovation for SME development in market turbulence", Eurasian Business Review, Vol. 7 No. 2, pp. 203-228.

Eniola, A.A. and Entebang, H. (2015), "Government policy and performance of small and medium business management", International Journal of Academic Research in Business and Social Sciences, Vol. 5 No. 2, pp. 237-248.

Farooq, S.U., Shams, M.S. and Niazi, M.M. (2015), "Factors affecting employees' performance: a case of kabul-based telecom firms", Business and Economic Review, Vol. 7 No. 2, pp. 71-84.

Garavan, T., Watson, S., Carbery, R. and O'Brien, F. (2016), "The antecedents of leadership development practices in SMEs: the influence of HRM strategy and practice", International Small Business Journal, Vol. 34 No. 6, pp. 870-890.

Goktan, A.B. and Gupta, V.K. (2015), "Sex, gender, and individual entrepreneurial orientation: evidence from four countries", International Entrepreneurship and Management Journal, Vol. 11 No. 1, pp. 95-112.

Harrison, R.T., Leitch, C.M. and McAdam, M. (2018), "Breaking glass: towards a gendered analysis of entrepreneurial leadership", Research Handbook on Entrepreneurship and Leadership, Edward Elgar Publishing.

Hayes, A.F. (2009), "Beyond Baron and Kenny: statistical mediation analysis in the new millennium", Communication Monographs, Vol. 76 No. 4, pp. 408-420.

Hayton, J.C. (2005), "Competing in the new economy: the effect of intellectual capital on corporate entrepreneurship in high technology new ventures", R\&D Management, Vol. 35 No. 2, pp. 137-155.

Hmieleski, K.M., Cole, M.S. and Baron, R.A. (2012), "Shared authentic leadership and new venture performance", Journal of Management, Vol. 38 No. 5, pp. 1476-1499.

Hoang, H. and Antoncic, B. (2003), "Network-based research in entrepreneurship: a critical review", Journal of Business Venturing, Vol. 18 No. 2, pp. 165-187.

Hurley, C.O. (2018), "MSME competitiveness in small island economies: a comparative systematic review of the literature from the past 24 years", Entrepreneurship and Regional Development, Vol. 30 Nos 9-10, pp. 1027-1068.

Jogaratnam, G. (2017), "The effect of market orientation, entrepreneurial orientation and human capital on positional advantage: evidence from the restaurant industry", International Journal of Hospitality Management, Vol. 60 No. 1, pp. 104-113.

Jong, J.P.D., Parker, S.K., Wennekers, S. and Wu, C.H. (2015), "Entrepreneurial behavior in organisations: does job design matter?", Entrepreneurship Theory and Practice, Vol. 39 No. 4, pp. 981-995.

Josien, L. (2012), "Entrepreneurial orientation: an empirical study of the risk-propensity dimension of entrepreneurs", Academy of Entrepreneurship Journal, Vol. 18 No. 1, p. 21.

Judge, T.A. and Piccolo, R.F. (2004), "Transformational and transactional leadership: a meta-analytic test of their relative validity", Journal of Applied Psychology, Vol. 89 No. 5, p. 755.

Jyoti, J., Chahal, H. and Rani, A. (2017), "Role of organisational learning and innovation in between high-performance HR practices and business performance: a study of telecommunication sector", Vision, Vol. 21 No. 3, pp. 259-273.

Khaksar, S. (2011), "The role of government policy and the growth of entrepreneurship in the micro, small (\&) medium-sized enterprises in India: an overview", Australian Journal of Basic and Applied Sciences, Vol. 5 No. 6, pp. 1563-1571. 

${ }_{1,1}^{\text {IRJMS }}$

Khan, M.A., Rathore, K. and Sial, M.A. (2020), "Entrepreneurial orientation and performance of small and medium enterprises: mediating effect of entrepreneurial competencies", Pakistan Journal of Commerce and Social Sciences (PJCSS), Vol. 14 No. 2, pp. 508-528.

Kittikunchotiwut, P. (2020), "The roles of organisational learning capability and firm innovation in the relationship between entrepreneurial orientation and firm performance", The Journal of Asian Finance, Economics, and Business, Vol. 7 No. 10, pp. 651-661.

Koryak, O., Mole, K.F., Lockett, A., Hayton, J.C., Ucbasaran, D. and Hodgkinson, G.P. (2015), "Entrepreneurial leadership, capabilities and firm growth", International Small Business Journal, Vol. 33 No. 1, pp. 89-105.

Krauss, A., Rūtelionè, A. and Piligrimienè, Z. (2010), "SME in Search for Feasible Concepts for Systematic Social Responsibility in Times of Crisis”, Economics and Management, No. 15, pp. 635-641.

Kusumawardhani, D., Rahayu, A.Y. and Maksum, I.R. (2015), "The role of government in MSMEs: the empowerment of MSMEs during the free trade era in Indonesia", Australasian Accounting, Business and Finance Journal, Vol. 9 No. 2, pp. 23-42.

Lavelle, J., Gunnigle, P. and McDonnell, A. (2010), "Patterning employee voice in multinational companies", Human Relations, Vol. 63 No. 3, pp. 395-418.

Leitch, C.M. and Volery, T. (2017), "Entrepreneurial leadership: insights and directions", International Small Business Journal, Vol. 35 No. 2, pp. 147-156.

Leitch, C.M., McMullan, C. and Harrison, R.T. (2013), "The development of entrepreneurial leadership: the role of human, social and institutional capital”, British Journal of Management, Vol. 24 No. 3, pp. 347-366.

Maheshwari, M., Samal, A. and Bhamoriya, V. (2020), "Role of employee relations and HRM in driving commitment to sustainability in MSME firms", International Journal of Productivity and Performance Management, Vol. 69 No. 8, pp. 1743-1764.

Man, T.W., Lau, T. and Chan, K.F. (2002), "The competitiveness of small and medium enterprises: a conceptualization with focus on entrepreneurial competencies", Journal of Business Venturing, Vol. 17 No. 2, pp. 123-142.

Mehta, S. and Kaur, M. (2021), "COVID-19 and Ludhiana's woolen knitwear industry: way forward”, Research Journal of Textile and Apparel, Vol. 25 No. 3, pp. 209-225.

Messersmith, J.G. and Guthrie, J.P. (2010), "High performance work systems in emergent organisations: implications for firm performance. Human resource management: published in cooperation with the school of business administration", The University of Michigan and in Alliance with the Society of Human Resources Management, Vol. 49 No. 2, pp. 241-264.

Muhammed, A.Y. and Abdulkadir, A. (2021), "Moderating effect of strategic thinking on the relationship between entrepreneurial orientation and micro small and medium enterprise performance", Fudma Journal of Management Sciences, Vol. 2 No. 2, pp. 47-59.

Musara, M. and Nieuwenhuizen, C. (2020), "Informal sector entrepreneurship, individual entrepreneurial orientation and the emergence of entrepreneurial leadership", Africa Journal of Management, Vol. 6 No. 3, pp. 194-213.

Panagiotakopoulos, A. (2013), "The impact of employee learning on staff motivation in Greek small firms: the employees' perspective”, Development and Learning in Organisations, Vol. 27 No. 2, pp. 13-15.

Porter, M.E. and Kramer, M.R. (2002), "The competitive advantage of corporate philanthropy", Harvard Business Review, Vol. 80 No. 12, pp. 56-69.

Quince, T. and Whittaker, H. (2003), "Entrepreneurial orientation and entrepreneurs' intentions and objectives”, Working Paper No. 271, ESRC Centre for Business Research, University of Cambridge.

Radomir, L. and Nistor, V.C. (2013), "An application of technology acceptance model to internet banking services”, The Proceedings of the International Conference' Marketing-from Information to Decision, Babes Bolyai University, p. 251. 
Rajan, S. and Panicker, S. (2020), "The concept of entrepreneurial ability-evidence from women in MSMEs of Karnataka state", International Journal of Entrepreneurship and Small Business, Vol. 41 No. 1, pp. 1-32.

Renko, M., Shrader, R.C. and Simon, M. (2012), "Perception of entrepreneurial opportunity: a general framework", Management Decision, Vol. 50 No. 7, pp. 1233-1251.

Renko, M., El Tarabishy, A., Carsrud, A.L. and Brännback, M. (2015), "Understanding and measuring entrepreneurial leadership style”, Journal of Small Business Management, Vol. 53, pp. 54-74.

Sahoo, P. and Ashwani (2020), "COVID-19 and Indian economy: impact on growth, manufacturing, trade and MSME sector", Global Business Review, Vol. 21 No. 5, pp. 1159-1183.

Sapienza, H.J., De Clercq, D. and Sandberg, W.R. (2005), “Antecedents of international and domestic learning effort", Journal of Business Venturing, Vol. 20 No. 4, pp. 437-457.

Sarasvathy, S.D., Dew, N., Velamuri, S.R. and Venkataraman, S. (2003), "Three views of entrepreneurial opportunity", in Handbook of Entrepreneurship Research, Springer, Boston, MA, pp. 141-160.

Sengupta, A., Datta, S.K. and Mondal, S. (2013), "Women's entrepreneurial abilities: a study in the Indian informal service sector", The Journal of Entrepreneurship, Vol. 22 No. 2, pp. 223-243.

Shanthakumar, D.K. (1992), Attitudinal Characteristics of Male and Female Entrepreneurs in India and a Comparison with American Entrepreneurs, Doctoral dissertation, Brigham Young University.

Simba, A. and Thai, M.T.T. (2019), "Advancing entrepreneurial leadership as a practice in MSME management and development”, Journal of Small Business Management, Vol. 57, pp. 397-416.

Socrates, K. and Gopalakrishna, B.V. (2020), "Indian government interventions in micro, small and medium enterprise development: an enterprise life cycle perspective", Colombo Business Journal, Vol. 11 No. 1, pp. 132-164.

Soomro, B.A. and Shah, N. (2019), "Determining the impact of entrepreneurial orientation and organisational culture on job satisfaction, organisational commitment, and employee's performance", South Asian Journal of Business Studies, Vol. 8 No. 3, pp. 266-282.

Subramaniam, R. and Shankar, R.K. (2020), "Three mindsets of entrepreneurial leaders", The Journal of Entrepreneurship, Vol. 29 No. 1, pp. 7-37.

Thoumrungroje, A. and Tansuhaj, P. (2005), "Entrepreneurial strategic posture, international diversification and firm performance", The Multinational Business Review, Vol. 13 No. 1, pp. 55-73.

Vaillant, Y. and Lafuente, E. (2007), "Do Different Institutional Framework condition the influence of local fear of failure and entrepreneurial examples over entrepreneurial activity?", Entrepreneurship and Regional Development, Vol. 19 No. 4, pp. 313-337.

Vogelsang, L. (2015), Individual Entrepreneurial Orientation: An Assessment of Students, Doctoral dissertation, Humboldt State University.

Wiklund, J. and Shepherd, D. (2005), "Entrepreneurial orientation and small business performance: a configurational approach", Journal of Business Venturing, Vol. 20 No. 1, pp. 71-91.

Zhao, X., Lynch, J.G. Jr and Chen, Q. (2010), "Reconsidering baron and kenny: myths and truths about mediation analysis", Journal of Consumer Research, Vol. 37 No. 2, pp. 197-206.

\section{Corresponding author}

Anirban Mandal can be contacted at: anirban3009@gmail.com

For instructions on how to order reprints of this article, please visit our website:

www.emeraldgrouppublishing.com/licensing/reprints.htm

Or contact us for further details: permissions@emeraldinsight.com 